2003

\title{
Products Liability Harmonization: A Uniform Standard
}

Rebecca Korzec

University of Baltimore School of Law, rkorzec@ubalt.edu

Follow this and additional works at: http://scholarworks.law.ubalt.edu/all_fac

Part of the Consumer Protection Law Commons, State and Local Government Law Commons, and the Torts Commons

\section{Recommended Citation}

Products Liability Harmonization: A Uniform Standard, 9 IUS Gentium 25 (2003)

This Article is brought to you for free and open access by the Faculty Scholarship at ScholarWorks@University of Baltimore School of Law. It has been accepted for inclusion in All Faculty Scholarship by an authorized administrator of ScholarWorks@University of Baltimore School of Law. For more information, please contact snolan@ubalt.edu. 


\title{
Products Liability Harmonization: A Uniform Standard
}

\author{
Rebecca Korzec \\ University of Baltimore
}

The purpose of products liability laws is to create safer products. In our global economy, a uniform approach to products liability law is the most effective means of fulfilling this purpose. American manufacturers market their products nationally and internationally. Worldwide, consumers buy products marketed through all means of interstate and international commerce, including the Internet. For this reason, any single product may be regulated by a variety of different state or international products liability laws. The application of these inconsistent rules may discourage essential manufacturer decision-making, may have a discriminatory impact upon some product manufacturers and users, and may lead to externalization of accident costs.

Among industrialized nations, the United States is unique in addressing tort law at the state rather than the national level. For example, Australia and Canada, which share a common-law heritage with the United States, have 


\section{Rebecca Korzec}

federal tort systems. The United States approach may be appropriate in some tort settings, such as in the premises liability or motor vehicle accident context (not involving a claim of products liability), where the state rule's impact remains within that state's geographical boundaries. Unlike the simple "fender-bender", which occurs within the borders of one state, the typical product is manufactured and marketed nationally or internationally. Therefore, several factors suggest that uniform federal treatment of product liability laws may be a more desirable means of regulation.

First, conflicting state rules create an absence of predictable standards for manufacturers. For example, while some states may employ the consumer expectations test for determining product defects, others may apply the risk utility test. To be efficient, manufacturers must mass-produce and market their products nationally. However, they may find it cumbersome, if not impossible, to comply with the conflicting rules of the various states in which the product is made or marketed. Manufacturers cannot always redesign their products to meet competing, inconsistent state requirements. Thus, conflicting rules not only discourage essential manufacturer planning and decisionmaking, they also jeopardize product design and safety. In sum, experimentation by the states in creating their own doctrines and regulations, 


\section{Products Liability Harmonization}

one of the supposed benefits of decentralization, actually may become a detriment.

Second, state lawmakers may legislate an inherent bias into products liability law, adopting rules that advance parochial interests, which favor resident product injury victims over national manufacturers. ${ }^{1}$ Conversely, a state may manipulate its product liability rules to advance its political or economic development goals, thereby creating a pro-manufacturer bias. This can be explained, at least in part, by some basic realities of the legislative process. Business or insurance interests, who possess substantial funds to underwrite intensive lobbying campaigns, may influence state legislators to create a more hospitable environment for out- of- state manufacturers. By contrast, product consumers not only underestimate product risks ${ }^{2}$, they also may underestimate the potential benefits of organized legislative advocacy. ${ }^{3}$ As a result, product users may overlook these activities, giving little reward to legislators who adopt a pro-

\footnotetext{
${ }^{1}$ See, e.g. Blankenship ข. Gen. Motors Corp., 406 S.E. 2d 781 (W.Va. 1991), in which the Supreme Court of West Virginia stated that, where a split of authority exists about which crashworthiness rule to apply, the court should choose the rule more favorable to the plaintiff.

2 See, e.g. Jon D. Hanson \& Douglas A. Kysar, "Taking Behavioralism Seriously: Some Evidence of Market Manipulation," 112 Harv. L. Rev. 1420 (1999). See also, Gary T. Schwartz, "Considering the Proper Federal Role in American Tort Law," 38 Ariz. $L$. Rev. 917, 936 (1996).

${ }^{3} I d$., Schwartz at 937.
} 


\section{Rebecca Korzec}

consumer stance. ${ }^{4}$ Thus, it is not surprising that most legislative tort reform favors insurance companies and sellers. ${ }^{5}$ The federal government can play an important neutralizing role in preventing such manipulation by states.

Third, because most products are manufactured and marketed nationally and internationally, the market for many products is sufficiently global to justify federal and international regulation. Congress already has recognized the advantages of uniform federal treatment of products liability issues. Nationally, the Food and Drug Administration, the Consumer Product Safety Commission and the National Highway Traffic Safety Administration are current examples of this federal approach.

There may be disadvantages inherent in the imposition of uniform federal products liability laws. State lawmaking is viewed as advancing autonomy, self-reliance, individualism, and independence. To the extent that states are prevented from controlling products liability laws, these goals may not be realized. Moreover, uniform national standards may ignore local voter concerns. Similarly, innovation, economic development, political representation, and voter

${ }^{4} I d$. 


\section{Products Liability Harmonization}

interests may be burdened by national standards that seem difficult to implement.

Can the obstacles created by non-uniformity be removed through the application of choiceof-law rules? A number of proposals have been advanced, including: 1) applying the state law where the manufacturer has the greatest number of employees; 2) applying the state law where the product is first sold; 3) permitting manufacturers to designate the applicable state law. ${ }^{6}$

Having seen the existence of nonuniformity and state law bias in American products liability law, it is important to consider these in the global context. The arguments in favor of federalization of products liability apply to globalization, as well. How might international law respond effectively to these concerns? First, a comprehensive code or treaty might internationalize all aspects of global products liability law. One immediate problem with this approach is whether products liability policy concerns would be addressed adequately, or whether they would be subjected to parochial political decisions. Unfortunately, politicization could jeopardize product safety if individual regimes consciously or inadvertently create disin-

${ }^{6}$ Schwartz, supra note 2 at 937. 


\section{Rebecca Korzec}

centives to safety and health measures by adopting rules that favor sellers.

Tobacco, as a product, offers a compelling argument for global regulation. The World Health Organization estimates that about 5 million people a year die from tobacco-related disease, including about 400,000 a year in the United States alone. This annual global death count is projected to be more than 8 million by 2020 and 10 million by $2030 .^{7}$ Seventy percent of these deaths will occur in developing countries. $^{8}$ As industrialized nations combat the tobaceo industry, these international companies focus their marketing efforts on developing nations.

Should the international tobacco problem be controlled by international treaty? In 1999 , the World Health Assembly (WHA), the governing body of the World Health Organization, agreed to have the WHO create a tobacco control treaty. The World Health Assembly adopted the Framework Convention on Tobacco Control (FGTC) on May 23, 2003. The FGTC, a legally binding treaty, is the first international public health treaty. It encourages countries to recog-

\footnotetext{
${ }^{7}$ Framework Convention Alliance-The Framework Convention on Tobaceo Control-FAQ; available at http://www.fetc.org/about FCTC/index.shtml ${ }^{8}$ Id.
} 


\section{Products Liability Harmonization}

nize and combat the global hazards presented by tobacco-related disease. ${ }^{9}$

The WHO justifies the need for an international treaty in several ways. First, " $[t]$ he tobacco epidemic is an international problem." Second, "[t]he tobacco industry is a global industry". ${ }^{11}$ Third, "[t]obacco industry marketing campaigns executed across a number of different countries simultaneously, including through satellite television;...." require global solutions. ${ }^{12}$

The ultimate question is what might such a treaty accomplish? What might collective action by the world's nations accomplish that the nations cannot achieve by their own initiatives? The treaty addresses measures that require international cooperation, such as regulating international advertising and combating international smuggling. These problems should receive priority in an international treaty because they require collective action and resources. Individual countries would receive benefits that they could not achieve on their own.

Moreover, a treaty focused on truly international issues is more likely to receive support

\footnotetext{
${ }^{9} I d$.

${ }^{10} I d$.

${ }^{11}$ Id.

${ }^{12}$ Id.
} 


\section{Rebecca Korzec}

for two reasons. First, individual countries may actually appreciate the benefits they will derive from these cooperative efforts. Second, the requirements imposed upon each individual country may not be burdensome. Nevertheless, countries with strong national tobacco control regimes may reject an international treaty that addresses substantive domestic policy. These nations with existing domestic controls may view their regimes as more effective than they might be under an international agreement. Moreover, they may fear that limited international controls could undercut strong domestic rules already in place. ${ }^{13}$

The framework international treaty may be viewed as a significant world health measure, encouraging nations to act collectively against global tobacco companies. Ultimately, tobacco control requires changing the attitudes of masses of people to make smoking unacceptable. Without an international approach to the global tobacco industry, such changes are unlikely to occur. The treaty is a timely and instructive example of global product regulation by a uniform standard.

13 Derek Yach and Douglas Bettcher, "Globalisation of tobacco industry influence and new global responses." Tobacco Control 2000; 9:206-216. 


\section{Products Liability Harmonization}

In sum, a uniform approach to products liability laws is the most effective means of creating safer products. Uniformity diminishes the ability of state lawmakers to advance merely parochial interests, or to favor business interests at the expense of the consumer. Finally, on an international level, uniformity advances global solutions to global problems. 
[34] IUS GENTIUM - Fall 2003 